\title{
SAMOTNOŚĆ SENIORÓW A RODZINA. WYZWANIA DLA OPIEKI PROFESJONALNEJ
}

\section{Streszczenie}

Artykuł podejmuje problematykę samotności i osamotnienia, które sa postrzegane przede wszystkim jako stany negatywne, i dla osób je przeżywajacych niosa różne nieprzyjemne konsekwencje łacznie z depresją. Samotność w sposób szczególny doskwiera osobom w podeszłym wieku, gdy kończa aktywność zawodowa, gdy zmniejsza się ich sieć towarzyska, gdy umierają najbliżsi. W niniejszym opracowaniu zwrócono uwagę na zamienne stosowanie w literaturze przedmiotu i języku potocznym pojęcia samotność i osamotnienie, takie stanowisko przyjęty również autorki. Zauważono ponadto tendencję do unikania jednoznacznego definiowania pojęcia ,człowiek stary”, stosując w zamian określenia typu: senior, seniorzy, lub osoby trzeciego, czwartego wieku, późnego wieku. Następnie odwołano się do przyczyn samotności seniorów, zwracając szczególna uwagę na rolę i znaczenie rodziny jako czynnika zmniejszającego ryzyko odczuwanej samotności. W artykule poruszono również zagadnienie profesjonalnej opieki i wyzwań przed nia stojących.

Słowa kluczowe: samotność, starość, osoby starsze, senior, profesjonalna opieka

* Ewa Sosnowska-Bielicz - mr pedagogiki i psychologii, asystent w Zakładzie Dydaktyki na Wydziale Pedagogiki i Psychologii Uniwersytetu Marii Curie Skłodowskiej w Lublinie.

* Joanna Wrótniak - dr n. społ. w zakresie pedagogiki, adiunkt w Zakładzie Teorii Wychowania na Wydziale Pedagogiki i Psychologii UMCS w Lublinie. 
„Człowiek rośnie i dojrzewa przez jedna czwarta część
swojego życia,
przez trzy czwarte - starzeje się. (...)
Wszyscy osobiście musimy interesować się procesem
starzenia,
ponieważ wszyscy będziemy przeżywać taki proces
$i$ wszyscy mamy kontakt z osobami starszymi.
A im więcej wiemy o starości tym lepiej będziemy
rozumieć samych siebie i innych”.

(D.B. Bromley) ${ }^{1}$

\section{Wstęp}

Już w latach 70 ubiegłego wieku Simone de Beauvoi w książce „Starość”, która powstała jak sama autorka przyznała „dla przełamania zmowy milczenia”, podjęła się wyzwania jakim jest dyskusja na temat starości i osób starszych, starając się stworzyć miejsce w przestrzeni naukowej i publicznej na tą problematykę. Autorki niniejszego tekstu kontynuując myśl Simene de Beauvoi w niniejszym tekście mierzą się z zagadnieniem samotności w życiu osób starszych, próbując w ten sposób zwrócić uwagę na nadal funkcjonujący stereotyp myślenia o osobach starszych jako zniedołężniałych, biernych i mniej wartościowych ${ }^{2}$. A przecież „,...) starcy to ci sami młodzieńcy, tyle tylko, że przeżyli sporo lat. Stary człowiek jest ciągle tą samą osobą wraz z jej wadami i zaletami”’3.

Globalne zmiany demograficzne zachodzące w społeczeństwach wysoko rozwiniętych konfrontują nas z koniecznością zmierzenia się z tematyką starości, starzenia się i dostosowaniem do rosnących oraz zmieniających się potrzeb i oczekiwań osób starszych. W końcu 2016 r. liczba ludności Polski wynosiła 38,4 mln, w tym ponad $9 \mathrm{mln}$ stanowiły osoby w wieku 60 lat i więcej (prawie 24\%). Wyniki prognozy ludności na lata 2014-2050 wskazują na pogłębianie się tego procesu,

\footnotetext{
D.B. Bromley, Psychologia starzenia się, PWN, Warszawa 1969, s. 13-14.

2 Por.: Badacz niemiecki R. Bartel wyróżnił kilka mitów dotyczących społecznych wyobrażeń starzenia się i starości. Są nimi: mit umocnienia się poglądów i postaw konserwatywnych, spadku możliwości dokonywania osiągnięć, utraty zdolności podejmowania decyzji i rozwiązywania problemów, zahamowania możliwości rozwoju (również możliwości intelektualnych), wreszcie mit aseksualności człowieka starego. za: Z. Szarota, Gerontologia społeczna i oświatowa. Zarys problematyki, AP, Kraków 2004, s. 50.

3 J. Hryniewicz, Los starca zależy od kontekstu społecznego-wprowadzenie, w: O sytuacji ludzi starszych, red. J. Hryniewicz, ZWS, Warszawa 2012, s. 17.
} 
populacja osób starszych wzrośnie do 13,7 miliona i będzie stanowiła ponad $40 \%$ ogółu ludności Polski

Poprawa jakości życia człowieka na wszystkich jego etapach życia w krajach wysokorozwiniętych jest faktem, rozwój medycyny spowodował, że długość życia przeciętnego człowieka uległa wydłużeniu. Większy dostęp do opieki medycznej nie jest gwarantem zdrowej starości. Specyficzne dla wieku senioralnego choroby nie zostały wyeliminowane, dlatego temat opieki i pomocy osobom starszym oraz jej różne formy są zagadnieniem ważnym. To co dla osoby starszej jest najtrudniejsze, to samotność, z która muszą się zmagać. Od osób opiekujących się nimi senior oczekuje, niejednokrotnie poza czynnościami pielęgnacyjnymi, przede wszystkim autentycznej obecności i zainteresowania ich osobą. Stanowić to może duże wyzwanie, szczególnie dla tak zwanej profesjonalnej, zinstytucjonalizowanej opieki.

Dlatego też tematyka związana z osobami starszymi ze względu na jej rangę powinna stanowić istotne zagadnienie zarówno w polityce, nauce, dyskusjach publicznych jak i profesjonalnych działaniach opiekuńczych..

\section{Senior, osoba starsza czy osoba w podeszłym wieku - próby zdefiniowania pojęcia}

Osoby, które przekroczyły utożsamiany ze starością wiek (jak dalej zostanie wykazane jest to niejasna i niezdefiniowana granica), są nazywane ludźmi starymi, osobami w starszym wieku, starcami lub seniorami, nie tylko w języku potocznym. Analizując literaturę przedmiotu można zauważyć, że w odniesieniu do starości stosowane są określenia: starość, późna dorosłość, jesień życia, wiek emerytalny, wiek senioralny, trzeci wiek, czwarty wiek zaś do osób: senior, emeryt, człowiek starszy ${ }^{5}$. Nie ma do końca wyraźnego i klarownego podziału przywołanych określeń, co więcej część z nich funkcjonuje na zasadzie synonimów. Józefina Hryniewicz we wstępie do książki „O sytuacji ludzi starszych” zauważa, że wielu autorów unika pojęcia „człowiek stary”, zastępując je wyrazami bliskoznacznymi typu: senior, seniorzy, lub osoby trzeciego, czwartego wieku, późnego wieku. Definiując je następująco: „Trzeci wiek to czas, gdy jednostka wolna jest od pracy zawodowej i zadań rodzicielskich, zaś czwarty wiek to czas życia, gdy jednostka ze względu na podeszły wiek traci samodzielność i niezależność, ma ograniczoną sprawność fizyczną i umysłową. Senior to ktoś najstarszy w danej

4 GUS, Prognoza ludności na lata 2014-2050, s. 133, prognoza dot. grupy wiekowej 65+. http://stat.gov.pl/obszary-tematyczne/ludnosc/prognoza-ludnosci/prognoza-ludnosci-na-lata-2014-2050-opracowana-2014-r-,1,5.html, data pobrania 30.08.2018.

5 Zob. S. Steuden, Psychologia starzenia się i starości, PWN, Warszawa 2012, s. 21. 
zbiorowości" precyzyjne i jednoznaczne. Nie definiuje starości jako naturalnej fazy życia człowieka następującej po zakończeniu aktywności zawodowej.

$\mathrm{W}$ istniejącym kulcie młodości zarówno w potocznym języku jak i literaturze naukowej dostrzegalne jest unikanie pojęć „stary”, ,starość” w opisie najstarszego pokolenia. Konsekwencją tego jest utrwalanie podziału życia człowieka na młody okres - jako dobry, lepszy czas życia, oraz ten gorszy - starość.

Trudno jednoznacznie wskazać na początek starości, jest on rozmyty, trudny do ustalenia zarówno na gruncie dyskursu naukowego, jak i w języku potocznym. Swoistym symbolem wejścia w starość bywa przejście na emeryturę, niemniej jednak okres ten kojarzony jest jednocześnie z byciem samotnym. Najczęściej populacja osób starszych w wieku 65 lat i więcej jest zbiorowością niejednorodną, dlatego też nie ma jednolitego stanowiska odnośnie do kryteriów początku starości i jej periodyzacji. Dzieje się tak na skutek wielu czynników, między innymi: zróżnicowanego tempa starzenia się, wydłużania się długości życia człowieka, jak również różnorodnego biologicznego, psychologicznego i społecznego wizerunku starości. W literaturze fachowej można spotkać wiele klasyfikacji okresu starości. W tabeli numer 1 zawarto wybrane periodyzacje omawianego etapu życia człowieka.

Tabela 1. Fazy starości według wybranych autorów

\begin{tabular}{|l|l|l|}
\hline \multirow{2}{*}{ Autor } & \multicolumn{2}{|c|}{ Klasyfikacja } \\
\cline { 2 - 3 } & \multicolumn{1}{|c|}{ przedzial wieku (lata) } & \multicolumn{1}{c|}{ nazwa przedzialu } \\
\hline \multirow{3}{*}{ Kamiński A. } & ok. 60 r.ż. & rozpoczynająca się starość \\
\cline { 2 - 3 } & ok. 75 r.ż. & wczesna starość \\
\cline { 2 - 3 } & powyżej 80 r.ż. & starość sędziwa \\
\hline \multirow{3}{*}{ Bochenek A. } & $60-70$ lat & I stopień starzenia się \\
\cline { 2 - 3 } & $70-80$ lat & II stopień starzenia się \\
\cline { 2 - 3 } & $80-90$ lat & III stopień starzenia się \\
\hline \multirow{3}{*}{ Bromley D. B. } & $60-65$ r.ż. & okres przedemerytalny \\
\cline { 2 - 3 } & $65-70$ r.ż. & okres emerytalny \\
\cline { 2 - 3 } & $70-90$ r.ż. & wiek starczy \\
\cline { 2 - 3 } & powyżej 90 r.ż. & wiek sędziwy \\
\hline
\end{tabular}

6 J. Hryniewicz, O sytuacji ludzi starszych, ZWS, Warszawa 2012, s. 11. 


\begin{tabular}{|c|c|c|}
\hline \multirow[t]{2}{*}{ Autor } & \multicolumn{2}{|c|}{ Klasyfikacja } \\
\hline & przedział wieku (lata) & nazwa przedziału \\
\hline \multirow[t]{2}{*}{ Klonowicz S. } & $\begin{array}{l}60-79 \text { lat dla kobiet } \\
65-79 \text { dla mężczyzn }\end{array}$ & Starość \\
\hline & $\begin{array}{l}\text { powyżej 80. roku życia dla obu } \\
\text { płci }\end{array}$ & starość sędziwa \\
\hline \multirow{3}{*}{$\begin{array}{l}\text { Światowa } \\
\text { Organizacja } \\
\text { Zdrowia } \\
\text { (WHO) }\end{array}$} & $60-74$ r.ż. & $\begin{array}{l}\text { wiek podeszły (tzw. wczesna starość) } \\
\text { „young- old” }\end{array}$ \\
\hline & $75-89$ r.ż. & $\begin{array}{l}\text { wiek starczy ( tzw. późna starość) } \\
\text { „old- ld” }\end{array}$ \\
\hline & 90 r.ż. i powyżej & $\begin{array}{l}\text { wiek sędziwy } \\
\text { (tzw. długowieczność) } \\
\text { „longlife” }\end{array}$ \\
\hline \multirow[t]{3}{*}{ Kocemba J. } & $60-75$ lat & $\begin{array}{l}\text { starość wczesna (tzw. III wiek, } \\
\text { tzw. young old) }\end{array}$ \\
\hline & $75-90$ lat & starość dojrzała (tzw. old old) \\
\hline & $90-110-120$ lat & $\begin{array}{l}\text { długowieczność (wiek sędziwy, tzw. } \\
\text { oldest old, long life) }\end{array}$ \\
\hline \multirow[t]{4}{*}{ Dzienio K. } & $60-69$ r.ż. & wiek początkowej starości \\
\hline & $70-74$ r.ż. & wiek przejściowy \\
\hline & $75-84$ r.ż. & wiek zaawansowanej starości \\
\hline & 85 lat i więcej & wiek niedołężnej starości \\
\hline \multirow[t]{2}{*}{ Super D.E. } & $65-70$ r.ż. & okres spowolnienia \\
\hline & powyżej 70 r.ż. & okres emerytury \\
\hline \multirow[t]{2}{*}{ E.H. Erikson } & $60-75$ r.ż. & Starość \\
\hline & $75+$ & podeszły wiek \\
\hline
\end{tabular}

Źródło: J. Wrótniak, Zasoby psychospołeczne osób w podeszłym wieku z poczuciem samotności, Lublin, 2015 s. 18.

Pomimo istniejących i przedstawionych powyżej wybranych periodyzacji okresu starości, trudno jednoznacznie wskazać granicę wiekową wyznaczającą starość, autorkom tekstu wydaje się właściwe wiązać początek starości z odsunięciem od aktywności i rozpatrywanie go bardziej przez pryzmat funkcjonalny niż chronologiczny.

W rozważaniach na temat starości, można zauważyć różne kierunki myślowe, część autorów skupia się na negatywnych zmianach w sferze biologicznej, psychicznej i społecznej inni zaś traktują tą fazę życia człowieka jako naturalną 
i nieuniknioną ale jednocześnie akceptowaną i wartościową (pozytywną) ${ }^{7}$. Współcześnie zaś obserwowane jest łączenie obu podejść i patrzenie na starość holistycznie, wskazując zarówno na pozytywne jak i negatywne aspekty tego okresu życia człowieka.

W Encyklopedii Pedagogicznej znajdujemy następującą definicję starości: „to naturalna faza życia, następująca po młodości i dojrzałości, wieńcząca dynamiczny proces starzenia się. Określana mianem końcowej tercji życia, jest utożsamiana ze spadkiem wydolności organizmu, utratą mobilności, osłabieniem sił immunologicznych (starość biologiczna, fizjologiczna), ograniczeniem zdolności przystosowania się do wszelkich zmian, a w kontekście socjoekonomicznym, nierzadko też z pauperyzacją, samotnością (starość psychiczna), koniecznością korzystania z pomocy innych (starość ekonomiczna) i funkcjonowaniem na marginesie życia społecznego (starość społeczna). Wiązane z nią ograniczenia biopsychiczne, deficyty zdrowotne i sprawnościowe powodują, że $\mathrm{z}$ reguły wpisywana jest $\mathrm{w}$ stereotyp degradacji i marginalizacji społecznej”". Również inni autorzy w tym Elżbieta Trafiałek, Anna Leszczyńska-Rejchert czy Władyslaw Pędich pisząc o starości i człowieku starym odnoszą się do fazowego ujmowania rozwoju człowieka i określają go jako naturalny etap w życiu człowieka, zaś osobę starszą ujmują jako tę, która przekroczyła próg starości czyli wkroczyła w trzecią fazę (tercję) życia9.

Interesujące oblicze starości człowieka starego przedstawił Jan Paweł II w liście skierowanym do ludzi starszych, gdzie zauważa zarówno te dobre jak i trudniejsze aspekty tego okresu życia podkreślając, że: „każdy wiek ma swoje zalety i zadania"10. Człowieka starego postrzega w pozytywnym świetle, jako mędrca, człowieka doświadczonego życiem i mogącego przekazać tą wiedze kolejnym pokoleniom „starzenie się, to czas nacechowany mądrością, którą przynoszą za sobą lata doświadczeń (...) W świetle nauczania i terminologii biblijnej starość jawi się zatem jako «czas pomyślny», w którym dopełnia się miara ludzkiego życia;

\footnotetext{
Zob. S. Steuden. Psychologia starzenia się ..., dz. cyt., s. 18-19.

8 T. Pilch, Encyklopedia Pedagogiczna XXI wieku, tom 5, ŻAK, Warszawa 2006, s. 945.

9 Por: E. Trafiałek, Człowiek stary, w: Encyklopedia Pedagogiczna XXI wieku, red. T. Pilch, tom 1, ŻAK, Warszawa 2003, s. 580; A. Leszczyńska-Rejchert, Człowiek starszy i jego wspomaganie-w stronę pedagogiki starości, WUWM, Olsztyn 2010 s. 1015; W. Pędich, Gerontologia i geriatria, w: Geriatria z elementami gerontologii ogólne. Podręcznik dla lekarzy i studentów, red. T. Grodzicki, J. Kocemba, A. Skalska, VM Media Sp z o.o. VM Group sp.k. (Grupa Via Medica), Gdańsk 2007, s. 3.

10 Jan Paweł II, List do osób w podeszłym wieku, Watykan 1999 https://opoka.org.pl/ biblioteka/W/WP/jan_pawel_ii/listy/do_starszych_01101999.html data pobrania: 4.09.2018.
} 
zgodnie z Bożym zamysłem wobec każdego człowieka jest to okres, w którym wszystko współdziała ku temu, aby mógł on jak najlepiej pojąć sens życia i zdobyć «mądrość serca» (...)"»l1. Pozytywne aspekty życia seniorów podkreślają również Agnieszka Nowicka czy Kinga Wiśniewska-Roszkowska zwracając uwagę na wartości, które seniorzy, osoby starsze wnoszą w życie rodziny i środowiska w którym żyją, ich przymiotem jest refleksyjność i mądrość życiowa wynikająca $\mathrm{z}$ doświadczenia życiowego ${ }^{12}$.

Pomimo funkcjonowania w literaturze wielu ujęć i definicji pojęcia starość, starzenie się, nadal aktualne wydają się słowa wybitnego polskiego psychiatry i filozofa profesora Antoniego Kępińskiego: „Starość, jest fazą życia końcową, po niej przychodzi tylko śmierć; ponieważ nikt jeszcze nie potrafił określić bez zastrzeżeń, co to jest życie, brak tej definicji przekreśla także możliwość bezdyskusyjnego zdefiniowania pojęcia starość’’13.

Analizując literaturę fachową zauważyć można niekończące się rozważania o tym, kto jest, a kto nie jest starym człowiekiem. Być może propozycja, przywoływanej już Józefiny Hrynkiewicz, aby za osoby stare uznawać te osoby, które same siebie określają jako osoby stare, może być odpowiedzią na istniejący ageizm ${ }^{14}$.

\section{Samotność osób starszych}

Człowiek jako istota stadna i społeczna do prawidłowego rozwoju i szczęśliwego życia potrzebuje innych ludzi, niezależnie od wieku, stanu zdrowia czy statusu ekonomicznego. Jednym z największych nieszczęść jakie może dotknąć człowieka jest życie w samotności bez rodziny, przyjaciół, znajomych. Samotność niezależnie od tego kogo dotyka niesie ze sobą negatywne konsekwencje na wielu płaszczyznach życia człowieka. Jednak dotyka ona szczególnie seniorów wywołując silne spustoszenie w ich życiu, co więcej wielu badaczy podejmujących tematykę suicydalną zauważa, że samotność i strach przed samotnością znacząco zwiększa ryzyko samobójstw wśród seniorów ${ }^{15}$. Jest to duży problem, wynikający między

11 Tamże.

12 A. Nowicka, Starość jako faza życia człowieka, w: Wybrane problemy osób starszych, red. A. Nowicka, Impuls, Kraków 2010; por. K. Wiśniewska-Roszkowska, Nowe życie po sześćdziesiatce, TUM, Wrocław 1994;

13 A. Kępiński, Rytm życia, WL, Kraków 1973, s 11.

14 Tamże, s. 11-12.

15 Por: E. Ringel, Gdy życie traci sens. Rozważania o samobójstwie, Glob, Szczecin 1987; B. Hołyst, Suicydogenne aspekty samotności, w: Zrozumieć samotność: studium interdyscyplinarne, P. Domeracki, red. W. Tyburski, WUMK, Toruń 2006. 
innymi z osłabienia więzi rodzinnych, rozluźnienia kontaktów międzypokoleniowych, rozwoju różnych form pomocy społecznej (Domy Pomocy Społecznej, Domy seniorów, itd. $)^{16}$. Zdaniem Anny Leszczyńskiej-Rejchert „,w okresie starości silniej niż w poprzednich fazach życia odczuwana jest potrzeba bezpieczeństwa, szacunku i przynależności. $Z$ wiekiem nasilają się potrzeby psychospołeczne oraz potrzeby materialnego zaspokojenia bytu, a w wieku późnej starości potrzeba opieki ze strony innych osób lub instytucji"'17.

Z kolei badania podłużne przeprowadzone w Szwecji w latach 2004-2011 nad zjawiskiem samotności wśród osób starszych (powyżej 70 roku życia), pokazały, że samotność wrasta wraz z wiekiem i szczególnie dotyka kobiety. Co więcej takie czynniki jak depresja czy wdowieństwo są dodatkowymi zmiennymi potęgującymi poziom odczuwanej samotności przez osoby starsze ${ }^{18}$. Dlatego konieczne jest podejmowanie dyskusji na temat samotności i osamotnienia osób starszych.

W literaturze gerontologicznej odróżnia się samotność od osamotnienia, traktując je jako dwa odmienne stany, ten pierwszy ujmowany jest jako obiektywny, a drugi jako subiektywny. Piszą o tym między innymi Leon Dyczewski, Jan Szczepański, Piotr Szukalski czy Jarun Dragest ${ }^{19}$. Wymienieni badacze samotność określają jako długie pozostawanie w odosobnieniu, brak uczestnictwa w życiu społecznym, a nawet jak podaje Józef Rembowski jest ona ,...złożonym i wielowymiarowym psychospołecznym doświadczeniem człowieka. Jest to nieprzyjemne uczucie, pojawiające się na skutek niezgodności pomiędzy oczekiwaniami a realnymi możliwościami. Należy do stanów emocjonalnych, w których jednostka jest świadoma izolacji od innych i niemożności działania na ich korzyśće' ${ }^{20}$. Z kolei osamotnienie rozumiane jest jako wewnętrzne i subiektywne odczuwanie, ma

16 Por: S. Rogala, Starość i jej konsekwencje społeczno-rodzinne, WSZiA, Opole 2010, s. 87.

17 A. Leszczyńska-Rejchert, Człowiek starszy... op. cit., s. 68.

18 L. Dahlberg, L. Andersson, K. McKee, C. Lennartsson, Predictors of loneliness among older women and men in Sweden : A national longitudinal study, ,Aging \& Mental Health", 2015/ 19, (5), s. 409-417. https://www.tandfonline.com/doi/full/10.1080/13607863.2 016.1247425?scroll=top\&needAccess $=$ true data pobrania: 06.09.2018.

19 L. Dyczewski, Ludzie starzy i starość w społeczeństwie i kulturze, KUL, Lublin 1994; Człowiek stary w rodzinie i społeczeństwie, KUL, Lublin 1996; J. Szczepański, Sprawy ludzkie, Czytelnik, Warszawa 1988; P. Szukalski, Poczucie samotności i osamotnienia wśród sędziwych seniorów, a ich sytuacja rodzinna, „Auxilium Sociale - Wsparcie Społeczne", 2005/2, s. 217-238; J. Drageset, G. Eide, B. Furnes i wsp, Loneliness, loss, and social support among cognitively intact older people with cancer, living in nursing homes - a mixed-methods study, „Clin Interv Aging” 2015, nr 10, s. 1529-1536.

20 J. Rembowski, Samotność, UG, Gdańsk 1992, s. 33. 
wymiar znacznie głębszy, bazuje na jakości i liczbie kontaktów międzyludzkich. Osamotnienie to przede wszystkim poczucie niezrozumienia, wyobcowania od ludzi mimo utrzymywania kontaktów z nimi. Utożsamiane bywa też z izolacją społeczną, przez którą rozumie się niewystarczający poziom integracji jednostki ze społeczeństwem ${ }^{21}$.

Chociaż jak wyżej wykazano samotność i osamotnienie stanowią dwa odmienne stany i należy je osobno rozpatrywać, to zarówno w literaturze naukowej jak i w języku codziennym te dwa terminy są stosowane zamiennie (np. Maria Łopatkowa, Jerzy Piotrowski ${ }^{22}$ ), podobny kierunek obrały autorki niniejszego artykułu. Posługując się terminem samotność rozumieją go zarówno jako obiektywny jak i subiektywny stan człowieka i stasują zamiennie z pojęciem osamotnienie. Jako ciekawostkę można dodać, że w języku angielskim zarówno samotność jak i osamotnienie tłumaczone są jako loneliness.

Rozważając zagadnienie samotności i osamotnienia seniorów należy przyjrzeć się bliżej przyczynom tego stanu. W opiniach badaczy tematu samotność ludzi starszych wiąże się przede wszystkim z:

- zanikiem modelu wielopokoleniowej,

- utratą kontaktu z pokoleniami,

- śmiercią współmałżonka,

- zamieszkaniem w instytucjonalnych środowiskach życia (DPS etc),

- pojawianiem i rozwijaniem się chorób wieku starczego,

- $\quad$ pesymistycznym nastawieniem do życia i brakiem konstruktywnych postaw wobec własnej starości ${ }^{23}$.

W literaturze wymieniane są również takie przyczyny jak zanikające więzi pomiędzy członkami rodziny, brak zaspokajania potrzeb i troski ze strony najbliższych, które prowadzą do specyficznego rodzaju samotności, mianowicie do

${ }^{21}$ C. Victor, S. Scrambler, J. Bond, A. Bowling, Loneliness in later life, w: Growing older: Quality of life in old age. Maidenhead, red. A. Walker, C. Hennessy, Open University Press, 2004, s. 107-126.

22 Por.: M. Łopatkowa, Samotność dziecka, WSiP, Warszawa 1983; J. Piotrowski, Miejsce człowieka starszego w rodzinie i społeczeństwie, PWN, Warszawa 1973.

23 Por.: E. Dubas, Edukacja dorostych w sytuacji samotności i osamotnienia, UŁ, Łódź 2000, s. 86-87; M. Cichocka, Samotność jako jedna z treści etykiety starości, w: Przeciw samotności, red J. Twardowska-Rajewska, UAM, Poznań 2005, s. 55-58; J. Stochmiałek, Samotność oraz starość w świetle koncepcji jakości życia, w: Przeciw samotności, red. J. Twardowska-Rajewska, UAM Poznań 2005, s. 29-46. 
samotności rodzinnej ${ }^{24}$. Ten rodzaj samotności wydaje się być istotny i ważny jeśli uznamy, że to rodzina od zawsze stanowiła pierwotny system opiekuńczy. Liczne badania naukowe wskazują na rodzinę jako najważniejsze środowisko życia człowieka niezależnie od wieku. Zarówno dla małego dziecka, dorastającego młodego człowieka, dorosłego czy seniora stanowi główne źródło oparcia i poczucia bezpieczeństwa. W kontekście podejmowanego tematu, rodzina na przestrzeni wieków była tym miejscem gdzie stary człowiek mógł godnie i szczęśliwie żyć, badania wskazują, że dla seniorów mieszkających zarówno w miastach jak i na wsi, rodzina stanowi najważniejsza grupę wsparcia ${ }^{25}$. Wraz z rozwojem uprzemysłowienia, wydłużania się długości życia człowieka osoby starsze są postrzegane jako mniej wartościowe, mniej potrzebne i instytucjonalne formy opieki przejmują rolę rodziny. Badania Dialog Population Policy Acceptance Study (PPAS) pokazują, że w Polsce nadal funkcjonuje przekonanie, że to zadaniem dzieci jest opieka nad starszymi rodzicami $(91 \%)^{26}$, co nie znaczy, że ma to miejsce w rzeczywistości.

\section{Wyzwania opieki nad seniorami}

W wyniku przeobrażeń cywilizacyjnych, przyspieszenia tempa życia, coraz większej ilości dorosłych którzy są aktywni zawodowo, a jednocześnie starzenie się społeczeństwa powoduje wzrost zapotrzebowania na alternatywne, pozarodzinne formy opieki nad seniorami. Rodzina będąca podstawową i najważniejszą „instytucję opiekuńczą" nie zawsze może wypełniać ten obowiązek samodzielnie, bez wsparcia. Chcąc zapewnić seniorowi jak najlepsze warunki życia, nie rezygnować ze stałego uczestnictwa seniora w życiu rodzinnym, podejmuje decyzję o zatrudnieniu profesjonalnego opiekuna, asystenta lub pielęgniarki. Wybór zależy od stopnia samodzielności i stanu zdrowia seniora. Kolejną alternatywą są ,poza rodzinne formy opieki”, które najczęściej określane są mianem instytucjonalnych

24 Rodzaj samotności wyodrębniony w Skali Społecznej i Emocjonalnej Samotności dla Dorosłych, E. Di Tommaso, B. Spinner, The development and initial validation of measure of social and emotional lonlines (SELSA), „Personality and Individual Differences” 14/1993; https://doi.org/10.1177/0013164403258450, data pobrania 6.09.2018.

25 Por.: M. Mossakowska, A. Więcek, P. Błędowski, Aspekty medyczne, psychologiczne, socjologiczne i ekonomiczne starzenia się ludzi w Polsce, Termedia Wydawnictwo Medyczne, Poznań 2012, s. 434-437.

26 M. Bryła, J. Maniecka-Bryła, Starzenie się ludności jako wyzwanie dla polityki zdrowotnej, „Polityka Społeczna”, nr 8/2009, s. 14-17. https:/www.researchgate.net/ publication/281348235_STARZENIE_SIE_LUDNOSCI_JAKO_WYZWANIE_DLA_ POLITYKI_ZDROWOTNEJ data pobrania: 04.09.2018. 
form opieki nad osobami starszymi. Wśród nich wyróżnić możemy: środowiskową opiekę zdrowotną, środowiskową opiekę geriatryczną (opieka dzienna dla dorosłych, opieka dla osób starszych lub ośrodek seniora, klub ludzi starszych), formą pośrednią pomiędzy opieką zakładową, a opieka domową i pomocą środowiskową jest dom dziennego pobytu lub dzienny dom opieki ${ }^{27}$.

W Polsce działalność takich instytucji regulowana jest Ustawą o Pomocy Społecznej z dnia 12 marca 2004 (Dz.U. nr 64, poz.593) ${ }^{28}$ wraz ze zmianami z dnia 8 lutego 2018 (Dz.U. 2018 poz. 700) ${ }^{29}$. Ustawa wskazuje na następujące rodzaje placówek opiekuńczych dla osób w podeszłym wieku: domy pomocy społecznej (DPS) dla osób w podeszłym wieku, placówki zapewniające całodobową opiekę osobom w podeszłym wieku (domy opieki) oraz rodzinne domy pomocy (RDP). Aby placówki opiekuńcze dla osób w podeszłym wieku mogły rozpocząć swoją działalność muszą uzyskać odpowiednie zezwolenie i zarejestrować się jako DPS, dom opieki lub RDP.

Warto zaznaczyć, że w zakresie instytucjonalnej opieki nad seniorami występuje przenikanie się dwóch systemów: pomocy społecznej i ochrony zdrowia. Jedną z przyczyn takiego stanu jest brak jednoznacznych wskaźników przyjmowania do poszczególnych typów instytucji, co powoduje, że niejednokrotnie dobór placówki dokonuje się przez przypadek (bo są wolne miejsca), a nie wynikają z prawidłowego rozpoznania i potrzeb osoby starszej. Przykładem tego może być kierowanie do domów pomocy społecznej osób somatycznie chorych, a do zakładów opiekuńczo-leczniczych (ZOL) i zakładów pielęgnacyjno-opiekuńczych (ZPO) osób nie wymagających stałej opieki medycznej ${ }^{30}$. Sektor ochrony zdrowia oferuje opiekę i pomoc nad osobami starszymi o charakterze instytucjonalną w ramach: oddziałów opieki paliatywnej, oddziałów dla osób przewlekle chorych, hospicjów, zakładów pielęgnacyjno-leczniczych, zakładów opiekuńczo-leczniczych.

$\mathrm{Z}$ perspektywy autorek tekstu wszelkie zinstytucjonalizowane, prowadzone przez osoby z kwalifikacjami i uprawnieniami działania sfokusowane na opiece i pomocy osobom starszym, można zaliczyć do profesjonalnych form opieki.

27 Por: J. Wrótniak, Zasoby psychospołeczne osób w podeszłym wieku z poczuciem samotności, UMCS, Lublin 2015

$28 \mathrm{http} / / /$ prawo.sejm.gov.pl/isap.nsf/download.xsp/WDU20040640593/O/D20040593. pdf, data pobrania: 28.09.2018.

29 http://prawo.sejm.gov.pl/isap.nsf/download.xsp/WDU20180000700/T/D20180700L. pdf, data pobrania: 28.09.2018.

30 A. Kozierkiewicz, K. Szczerbińska, Opieka dtugoterminowa w Polsce, ocena stanu obecnego oraz rozwiązania na przyszłość, Wydawnictwo Wspólny Rynek Medyczny, Kraków 2007, s. 23. 
Analizując badania nad jakością życia pacjentów geriatrycznych Aleksandra Zielińska ${ }^{31}$ i jej współpracownicy wskazali na konieczność kompleksowej oceny pacjenta geriatrycznego. Pozwala to na dostrzeżenie braków w zakresie samodzielności seniorów, co stanowi jedno z ważniejszych wyzwań dla profesjonalnej opieki. Właściwa diagnoza wstępna, ocena możliwości oraz deficytów seniora jest gwarantem optymalnej opieki. Profesjonaliści koncentrują się przede wszystkim na zaspokojeniu podstawowych potrzeb biologicznych osoby starszej, zapominając o potrzebach psychospołecznych. Co stwarza poczucie pustki, samotności niesie ze sobą cierpienia, wyzwala mechanizmy obronne a nawet prowadzić może do konfliktów osób starszych z otoczeniem. Zatem wyzwaniem w profesjonalnej opiece jest zapewnienie seniorom odpowiedniej opieki, wsparcia, poszanowania ich praw, godnego traktowania, aktywizacji i rehabilitacji (leczniczej i społecznej). Jak pokazują badania osoby starsze wskazują na potrzebę otrzymywania od swoich opiekunów wsparcia emocjonalnego związanego z empatią oraz życzliwością ${ }^{32}$. Współcześnie, największym wyzwaniem dla opiekunów osób starszych, jest praca zgodna z propagowaną ideą podejścia holistycznego do opieki nad seniorami. Idea ta opiera się na równoważnym uwzględnieniu aspektu fizycznego, psychicznego i społecznego jako warunku dobrostanu. Zatem właściwa ocena potrzeb (również tych niewyrażonych wprost) seniora i wyście im naprzeciw, jest ogromnym wyzwaniem ale też gwarantem satysfakcji ze świadczonych usług przez profesjonalnych opiekunów.

\section{Zamiast podsumowania - rodzina jako antidotum na samotność seniorów}

Rodzina jest naturalnym środowiskiem życia człowieka. Seniorzy coraz częściej jednak, jak wyżej zauważono, żyją poza rodziną, a ten okres swojego życia spędzają samotnie, w różnych instytucjach. Joanna Wrótniak podjęła tematykę poczucia samotności osób starszych w różnych środowiskach życia. W ramach swoich badań porównała jak seniorzy zamieszkujący z rodziną i przebywający w warunkach

31 A. Zielińska, M. Strugała, M. Stachowska, Ocena funkcjonowania czynnościowego, poznawczego oraz ryzyka rozwoju odleżyn, jako zasadniczych elementów w planowaniu zapotrzebowania na opieke pielegniarska u pacjentów $w$ wieku podeszłym, „Problemy Higieny i Epidemiologii” 2007, nr 88(2), s. 216-220.

32 I. Zaczyk i in., Zadania pielęgniarki środowiskowej związane z potrzebami ludzi starszych na podstawie wyników grup fokusowych przeprowadzonych w ramach projektu europejskiego PROGRESS: „,Zwiększenie dostępu do środowiskowych form opieki dla osób starszych, mieszkających we własnych gospodarstwach domowych”, „Problemy Pielęgniarstwa" 2011, tom 19, zeszyt nr 2 ViaMedica, s. 239-243. 
instytucjonalnych radzą sobie z samotnością, jakimi zasobami osobistymi dysponują oraz jak wpływa na nich dostępna sieć wsparcia społecznego. Dane uzyskane w toku badania pokazują, że osoby pozostające pod opieką rodziny uzyskiwały istotnie statystycznie niższe wyniki we wszystkich analizowanych wymiarach poczucia samotności w porównaniu z pensjonariuszami domów pomocy społecznej ${ }^{33}$. Wyniki te korespondują z danymi jakie uzyskała między innymi Elżbieta Trafiałek czy Andrzej Mielczarek, które podkreślają, że zerwanie i unikanie kontaktów rodzinnych jest czynnikiem, który w największym stopniu warunkuje powstanie samotności wśród seniorów ${ }^{34}$. Zatem środowisko życia, bliskość osób znaczący (dzieci, wnuków, rodziny) jest ważnym lub nawet bardzo ważnym czynnikiem modyfikującym poziom odczuwanej samotności wśród seniorów.

Stosunek i nastawienie do osób starszych na przestrzeni wieków było różne, jedni ośmieszali starość, inni przeklinali jeszcze inni nawoływali do szacunku. D.B. Bromley pisał, że „społeczeństwa można oceniać, na podstawie ich stosunku do ludzi starych. Istnieją nawet poglądy głoszące, że prawdziwie cywilizowane społeczeństwo uczyniłoby ze starości szczytowy kres życia"35. Interesujące badania przedstawiła Olga Dąbska, która wraz ze współpracownikami przyglądała się starości oczami młodych ludzi. Okazało się, że badani studenci zauważają zjawisko samotności wśród seniorów, problem ten dostrzega aż 85,5\%, a wśród czynników warunkujących to zjawisko wymieniają nie tylko pogarszanie się zdrowia i rosnącą zależność od innych ale również ograniczenie kontaktów osób starszych z najbliższą rodziną, nieakceptowanie ich przez młodsze pokolenia, brak tolerancji czy nieżyczliwe zachowania, odrzucenie. Jednak najważniejszym determinantem poczucia osamotnienia seniorów, według badanych studentów jest śmierć partnera życiowego i brak bliskiej osoby ${ }^{36}$. Potwierdzenie takich przyczyn samotności znajdziemy również u innych badaczy, którzy pytali o nie samych

33 J. Wrótniak, Zasoby psychospołeczne osób w podeszłym wieku z poczuciem samotności, UMCS, Lublin 2015.

34 E. Trafiałek, Człowiek starszy w Polsce w latach 1994-1997 w świetle analiz statystycznych i sondaży społecznych, WNŚ, Katowice 1997; A. Mielczarek, Adaptacja człowieka starszego do życia w domu pomocy społecznej, „Starość, roczniki naukowe Caritas” 2006, nr 10, s. 24-40.

35 D.B. Bromley, Psychologia starzenia sie..., dz. cyt.

36 O. Dąbska i współ., Starość i samotność osób starszych w percepcji ludzi młodych, „Medycyna Ogólna i Nauki o Zdrowiu” 2016, nr 2, s. 140-144; http://www.monz.pl/Starosci-samotnosc-osob-starszych-w-percepcji-ludzi-mlodych,73647,0,1.html, data pobrania: 3.09.2018. 
seniorów. W badaniach Joanny Plak śmierć współmałżonka ${ }^{37} \mathrm{i}$ brak bliskiej rodziny (dzieci mieszkające w dużej odległości) osoby starsze wskazywały jako główny determinant swojej samotności ${ }^{38}$. Z badań Piotra Czekanowskiego wynika, że samotność doskwiera osobom starszym, najbardziej tym w przedziale wiekowym 65-74 lata (blisko 60\%). Wśród osób najczęściej doświadczających samotności przeważali ludzie żyjący w stanie wolnym z wyboru lub konieczności, częściej są to kobiety niż mężczyźni. Dobry kontakt seniora z dziećmi może zmniejszać jego poczucie samotności, to właśnie dzieci są wskazywane jako te do których seniorzy zwróciliby się w sytuacji trudnej (ponad 80\%), co więcej z badań wynika, że nigdy lub prawie nigdy nie odczuwało samotności $66,6 \%$ osób starszych, które mają bardzo dobre relacje ze swoimi dziećmi, a często lub prawie zawsze odczuwało samotność prawie połowa osób, które miały niewłaściwe kontakty z dziećmi ${ }^{39}$. Koresponduje to $\mathrm{z}$ badaniami Aleksandry Błachnio nad zadowoleniem z życia osób starszych, które pokazały, że najmniej zadowoleni ze swojego życia są osoby starsze mieszkające samotnie, nieco bardziej zadowoleni są seniorzy mieszkający ze swoimi dorosłymi dziećmi i ich rodzinami, a najbardziej zadowoleni ze swojego życia są ci mieszkający ze współmałżonkiem ${ }^{40}$.

Powyżej przywołane badania są pewnym fragmentem dyskursu w naukach społecznych nad problematyką starości i osób starszych. Pokazują one jednak, że osoby starsze - seniorzy wolą wokół siebie widzieć osoby bliskie, z rodziny, że pozostawanie w bliskości fizycznej, emocjonalnej i psychicznej z własnymi dziećmi zmniejsza ryzyko samotności i wiążących się z nią konsekwencji.

\section{Bibliografia}

Błachnio A., Jakość i strategie życia w starości, w: Psychologia starzenia się i strategie dobrego życia, red. A. Błachnio, K. Kuryś-Szyncel, E. Martynowicz, A. Molesztak, Difin, Warszawa 2017, s. 61-80.

37 Por: Według skali oceny przystosowania społecznego, opracowanej przez Holmesa i Rahe'a, badającej poziom stresu związanego z określonymi wydarzeniami życiowymi i ogólny poziom stresu, śmierć współmałżonka ma najwyższą wartość - 100 punktów.

38 Por: Loneliness in older people - Live Well - NHS Choices, http://www.nhs.uk/ Livewell/women60-plus/Pages/Loneliness-in-olde data pobrania: 05.09.2018.

39 P. Czekanowski, Rodzina w życiu osób starszych i osoby starsze w rodzinie, w: Polska starość, red. B. Synak, UG, Gdańsk 2002, s. 154-168.

40 A. Błachnio, Jakość i strategie życia w starości, w: Psychologia starzenia się i strategie dobrego życia, red. A. Błachnio, K. Kuryś-Szyncel, E. Martynowicz, A. Molesztak, Difin, Warszawa 2017, s. 61-80. 
Bromley D.B., Psychologia starzenia się, PWN, Warszawa 1969.

Bryła M., Maniecka-Bryła J., Starzenie się ludności jako wyzwanie dla polityki zdrowotnej, „Polityka Społeczna” 2009, nr 8, s. 14-17.

Cichocka M., Samotność jako jedna z treści etykiety starości, w: Przeciw samotności, red J. Twardowska-Rajewska, UAM, Poznań 2005, s. 55-58.

Czekanowski P., Rodzina $w$ życiu osób starszych $i$ osoby starsze $w$ rodzinie, w: Polska starość, red. B. Synak, UG, Gdańsk 2002, s. 154-168.

Dahlberg L., Andersson L., McKee K., Lennartsson, Predictors of loneliness among older women and men in Sweden : A national longitudinal study, „Aging \& Mental Health" 2015, nr 19 (5), s. 409-417.

https://www.tandfonline.com/doi/full/10.1080/13607863.2016.1247425?scroll=top\& needAccess=true data pobrania: 06.09.2018.

Dąbska O., i współ. Starość i samotność osób starszych w percepcji ludzi młodych, „Medycyna Ogólna i Nauki o Zdrowiu” 2016, nr 2, s. 140-144.

http://www.monz.pl/Starosc-i-samotnosc-osob-starszych-w-percepcji-ludzimlodych,73647,0,1.html, data pobrania: 03.09.2018.

Dubas E., Edukacja dorosłych w sytuacji samotności i osamotnienia, UŁ, Łódź 2000.

GUS, Prognoza ludności na lata 2014-2050, s. 133, prognoza dot. grupy wiekowej 65+. http://stat.gov.pl/obszary-tematyczne/ludnosc/prognoza-ludnosci/ prognoza-ludnosci-na-lata-2014-2050-opracowana-2014-r-,1,5.html, data pobrania: 30. 08.2018.

Hrynkiewicz J., Los starca zależy od kontekstu społecznego - wprowadzenie, w: O sytuacji ludzi starszych, red. J. Hrynkiewicz, ZWS, Warszawa 2012.

Jan Paweł II, List do osób w podesztym wieku, Watykan 1999 https://opoka.org. pl/biblioteka/W/WP/jan_pawel_ii/listy/do_starszych_01101999.html, data pobrania: 04.09.2018.

Kępiński A., Rytm życia, WL, Kraków 1973.

Kozierkiewicz A., Szczerbińska K., Opieka dtugoterminowa w Polsce, ocena stanu obecnego oraz rozwiąania na przyszłość, Wydawnictwo Wspólny Rynek Medyczny, Kraków 2007.

Leszczyńska-Rejchert A., Człowiek starszy i jego wspomaganie-w stronę pedagogiki starości, WUWM, Olsztyn 2010.

Mossakowska M., Więcek A., Błędowski P., Aspekty medyczne, psychologiczne, socjologiczne i ekonomiczne starzenia się ludzi w Polsce, Termedia Wydawnictwo Medyczne, Poznań 2012, s. 434-437.

Nowicka A., Starość jako faza życia człowieka, w: Wybrane problemy osób starszych, red. A. Nowicka, Impuls, Kraków 2010. 
Pędich W., Gerontologia i geriatria, w: Geriatria z elementami gerontologii ogólne. Podręcznik dla lekarzy i studentów, red. T. Grodzicki, J. Kocemba, A. Skalska, VM Media Sp z o.o. VM Group sp. k. (Grupa Via Medica), Gdańsk 2007, s.43-54. Pilch T., Encyklopedia Pedagogiczna XXI wieku, Tom 5, ŻAK, Warszawa 2006. Rembowski J., Samotność, UG, Gdańsk 1992.

Rogala S., Starość i jej konsekwencje społeczno-rodzinne, WSZiA, Opole 2010. Steuden S., Psychologia starzenia się i starości, PWN, Warszawa 2012.

Stochmiałek J., Samotność oraz starość w świetle koncepcji jakości życia, w: Przeciw samotności, red. J. Twardowska-Rajewska, UAM Poznań 2005, s. $29-46$.

Victor C., Scrambler S., Bond J., Bowling A., Loneliness in later life, w: Growing older: Quality of life in old age. Maidenhead, red. A. Walker, C. Hennessy, Open University Press, 2004, s. 107-126.

Wiśniewska-Roszkowska K., Nowe życie po sześćdziesiątce, TUM, Wrocław 1994.

Wrótniak J., Zasoby psychospołeczne osób w podeszlym wieku z poczuciem samotności, UMCS, Lublin 2015.

Zaczyk I. i in., Zadania pielęgniarki środowiskowej zwiąane z potrzebami ludzi starszych na podstawie wyników grup fokusowych przeprowadzonych w ramach projektu europejskiego PROGRESS: „Zwiększenie dostępu do środowiskowych form opieki dla osób starszych, mieszkajacych we własnych gospodarstwach domowych”, „Problemy Pielęgniarstwa” 2011, tom 19, zeszyt nr 2 ViaMedica, s. 239-243.

Zielińska A., Strugała M., Stachowska M., Ocena funkcjonowania czynnościowego, poznawczego oraz ryzyka rozwoju odleżyn, jako zasadniczych elementów $w$ planowaniu zapotrzebowania na opieke pielegniarska u pacjentów $w$ wieku podesztym, „Problemy Higieny i Epidemiologii” 2007, nr 88(2), s. 216-220.

\section{Ewa Sosnowska-Bielicz, Joanna Wrótniak: Family and the loneliness of seniors. Challenges for professional care}

\section{Summary}

The article focuses on the issues of loneliness and isolation, which are seen primarily as negative states, and carry various unpleasant consequences for those experiencing them, including depression. Loneliness afflicts the elderly in a special way, when they end their professional activity, when their social network decreases, when their loved ones die. This study draws attention to the interchangeability of the notion of loneliness and isolation in the literature of the subject as well as in everyday language, which position is also shared by the authors. There was also 
a tendency to avoid unambiguous definition of the term "old man", using instead the terms of the type: senior, seniors, or people of the third, fourth and late age. Then, the reasons for loneliness of seniors were briefly addressed, paying special attention to the role and importance of the family as a factor reducing the risk of loneliness. The article also discusses the issue of professional care and the challenges facing it.

Key words: loneliness, old age, elderly people, senior, professional care 